Quarterly

ISSN $1898-2255$

Vol. 13 , No. $2 / 2014$

http://www.ekonomia.i.prawo.umk.pl
Article details:

Received: 16.10 .2013

Revised: 26.10 .2014

Accepted: 03.11.2014

Czech S., Institutions as enabling constraints. A note on social norms, social change and economic development, „Ekonomia i Prawo. Economics and Law.”, Polszakiewicz B., Boehlke J. (ed.), Vol. 13, No. 2/2014, pp. 309-319. DOI: http://dx.doi.org/10.12775/EiP.2014.023.

\title{
INSTITUTIONS AS ENABLING CONSTRAINTS. A NOTE ON SOCIAL NORMS, SOCIAL CHANGE AND ECONOMIC DEVELOPMENT
}

\author{
SUMMARY
}

Both formal and informal institutions are usually perceived as constraints that structure and limit human behavior. This is understandable when we use them as an addition to neoclassical economics and as an attempt to overcome its deficiencies. Yet institutions also enable behavior which would otherwise probably be inexistent. This paper aims to highlight the enabling feature of institutions and briefly recognizes selected consequences of it. We argue (1) that because institutional arrangements cause specific distribution results thus the process of institutional change is virtually infinite and does not have to lead to socially optimal effects and (2) that informal institutions (social norms) have today important explanatory and creative power for the existing social order and economic development. We conclude by suggesting that more interdisciplinary approach to economics may contribute to our better understanding of socioeconomic reality and indicate promising threads of current research.

Keywords: institutions, institutional change, social order, economic evolution JEL Classification: D01, D02, H10

* Sławomir Czech, University of Economics in Katowice, Faculty of Economics, Department of Economics, ul. 1 Maja 50, 40-276 Katowice, phone: +48 3225772 67, sczech@ ue.katowice.pl. 


\section{INTRODUCTION}

When we consider institutions as constraints we focus only on one of their sides, because they not only limit our behavior, but also enable other actions. This is often an unaccredited feature of institutions which calls for better recognition. In this paper we intend to elaborate shortly on some consequences of the enabling side of institutions that concerns social order and economic development. In order to do so we base our deductive reasoning on a critical survey of seminal literature which discloses the way leading scholars understand the notion of institutions. On this background we argue that because of the constant change of institutional arrangements any reached social equilibrium is only temporary and that social norms should be treated as an important factor of economic processes. Economics can thus only benefit from broadening its field of research to social aspects of reality.

The paper is divided into three sections. First section focuses on the way institutions are defined in the literature. Second section elaborates on selected consequences of the enabling feature of institutions, that is on distributional effects of institutional arrangements and the dynamics that follows from it as well as on the meaning of informal institutions (social norms) in the creation of social order. Third, concluding section finds a relation between social norms and economic development and calls for an extension of economic research to other social sciences.

\section{INSTITUTIONS ARE NOT MERELY CONSTRAINTS}

According to the classic definition by Douglass C. North institutions are "humanly devised constraints that structure political, economic and social interaction" ${ }^{1}$. Institutions are therefore rules of the game, both formal (like law or property rights) and informal (like social norms, customs or rules of conduct), that set the possible choices of action. In other words they determine transaction costs and transaction possibilities influencing the rate of return for any economic activity. For North the analysis of institutions refers basically to the "economic theory of choice subject to constraints" 2 . North asks openly what kind of institutional constraints cause that certain societies do not take up optimal activities leading to social wealth and welfare even though a high

${ }^{1}$ D.C. North, Institutions, „Journal of Economic Perspectives”, Vol. 5, No. 1/1991, p. 97.

${ }^{2}$ D.C. North, Institutional Change: A Framework of Analysis, „Economic History”, 1994, http://128.118.178.162/eps/eh/papers/9412/9412001.pdf (02.10.2013), p. 2. 
payoff seems to be at hand. Why do these constraints - norms, rules, laws, culture etc. - cause that resource allocation is ineffective and actions taken by actors are suboptimal? Transaction costs are thus derived not only from human analytical and procedural deficiencies or imperfect information, but also from institutions that structure human behavior. These constraints are responsible for the fact that market mechanism in the real world is far from being frictionless and far from maximizing actors' welfare.

Many scholars perceive institutions in a very similar way. For example Masahiko Aoki sees institutions as "a self-sustaining system of shared beliefs about how the game is played" ${ }^{3}$. Interactions of actors are governed in a selfenforcing manner and the rules are reproduced by actors' choices in order to achieve better coordination of their actions and goals in the future. Aoki is interested in how all the domains of institutional matrix come about and why there is a huge diversity among institutions; he seeks an explanation of how the institutional equilibrium is determined or negotiated. A very similar approach to institutions is employed by Avner Greif, who defines them as "a system of rules, beliefs, norms, and organizations that together generate a regularity of (social) behavior" ${ }^{4}$ in order to trace trajectories of development of various societies and investigate institutional persistence and change. Wolfgang Kasper et al. treat institutions as "a man-made rules which constrain people's (possibly arbitrary and opportunistic) behavior in human interaction" 5 . And finally Stefan Voigt sees them as "commonly known rules used to structure recurrent interaction situations that are endowed with a sanctioning mechanism" ${ }^{6}$. What all these definitions share in common is a view of institutions as socially designed constraints that affect human behavior and thus actors' view of the world, their decisions and actions taken. They are the reason why specific coordination and organizational patterns prevail in a given society determining effectiveness and welfare of a social order.

Institutions, however, should not be perceived exclusively as constraints that structure, determine and frame human behavior. There is something more to it. Institutions also enable certain actions which probably would not even be considered if the institutions did not exist, because the risk of performing them would be too high or expected pay-off would be too low. Institutions

${ }^{3}$ M. Aoki, Toward a Comparative Institutional Analysis, MIT Press, Cambridge 2001, p. 26.

${ }^{4}$ A. Greif, Institutions and the Path to the Modern Economy, Cambridge University Press, Cambridge 2006, p. 30.

${ }^{5}$ W. Kasper, M.E. Streit, P.J. Boettke, Institutional Economics. Property, Competition, Policies, Edward Elgar, Cheltenham 2012, p. 32.

${ }^{6}$ S. Voigt, How (Not) to Measure Institutions, "Journal of Institutional Economics”, Vol. 9, No. $1 / 2013$, p. 5. 
are important because they come handy in drawing a mental picture of the world around us; they construct the perceived reality and make it more predictable thanks to expectations of stable patterns of behavior of other people and a specific level of trust towards the societal system of human interactions. Institutions are responsible for ordering and coordinating otherwise chaotic and unpredictable reality even if this happens only in actors' minds through the creation of expectations or maybe even stereotypes. Thanks to both formal and informal institutions people feel safe (in the sense of property rights) to establish an enterprise, accept checks, buy stocks or trust their business partners and customers. To sum up, institutions reduce uncertainty due to designing a framework of possible actions and/or simplifying the way the world works thus facilitating people's everyday functioning and alleviating their limited cognitive and analytical abilities.

We do not claim that the above picture of institutions does not exist in the literature at all. It is, however, often mentioned implicitly and remains usually in the background. Only some scholars overtly take account of this feature. Hodgson for example claims that "institutions both constrain and enable behavior" 7 . They open up many possibilities of action relying on a given set of institutions. The same position is shared by John Groenewegen et al., although not in the very definition of institutions ${ }^{8}$. The scholarly focus on institutions as constraints that structure human behavior is absolutely understandable when we pinpoint the research agenda of neoinstitutional economics. This view of institutions serves as a tool to understand why there are differences in wealth between societies, differences in their paths of development or differences in allocative efficiency. Neoinstitutionalists broaden the methodological assumptions of neoclassical economics by admitting that humans have bounded rationality and may act irrationally thus not maximizing their welfare. They also employ new tools that serve to better explain and understand economic reality, like issues of property rights, public choice and path-dependency ${ }^{9}$. This is the way that neoinstitutional economics aims at complementing mainstream neoclassical economics, which has so far not offered satisfactory explanations for these phenomena. A view of institutions that enable certain actions is of minor importance and very limited applica-

7 G.M. Hodgson, What Are Institutions?, „Journal of Economic Issues”, Vol. 40, No. 1/2006, p. 2.

${ }^{8}$ J. Groenewegen, A. Spithoven, A. van den Berg, Institutional Economics, Palgrave Macmillan, Basingstoke 2010, p. 30.

9 See A. Ząbkowicz, Wspótczesna ekonomia instytucjonalna wobec gtównego nurtu ekonomii, „Ekonomista”, No. 6/2003. 
bility when one wishes to scrutinize economic efficiency of a given configuration of laws and norms or to check if one should choose hierarchical or market coordination of transactions. Issues of time, dynamics or evolution are thus reasonably omitted.

Bearing the above reservations in mind, we take notice of the fact that all institutional arrangements constrain a given set of actions, yet at the same time allow for actions of another kind, both within the constraints and outside them if the enforcement of institutions leaves much to be desired or the rate of return of acting so exceeds real and potential costs of action. Therefore every institution existing in time $t 1$ will bear certain consequences in time $t 2$; $t 3 ; \ldots ;$ th although these are largely unknown owing to unpredictability of human behavior as well as exogenous factors like natural disasters, policy failures or market crashes. We also feel obliged here to stress that institutions are not incentives. The fact that an institution enables certain action does not mean that it causes or provokes it. Humans react to incentives and only after the incentive has been created they match it against existing institutions to find out costs of the action in mind. An internalized set of social norms may also cause that an incentive for a certain action, like stealing or harming someone, shall not even cross one's mind. Furthermore, a given set of institutions may enable many possible ways of acting and it is only up to incentives if and which action will be chosen. Incentives and institutions are thus complementing and influencing each other, but they should be clearly differentiated.

\section{SOME CONSEQUENCES OF THE ENABLING FEATURE OF INSTITUTIONS}

From the fact that institutions hold the enabling function for human behavior one may draw a few conclusions. We definitely do not intend to name them all, but instead we would like to focus on two implications which may prove useful for studying and understanding the process of institutional and economic change. The way a society is organized determines how formal rules work and how these rules are changed. However, the change of rules may come not only from within the legal framework, but also by rejecting or omitting it. This is where economy and politics tightly intertwine as the political process of institutional change may be explained in economic terms and economic processes may be understood through political prism of coercion and violence.

The first thing is that each and every institutional arrangement creates specific distributional consequences in two spheres: economic and political 
one. The economic sphere refers to the market-related distribution of wealth and income and to the process of production, whereas the political sphere determines where the power of creating formal rules of the game is as well as who has the means to enforce and execute these rules. Daron Acemoglu and James A. Robinson have elaborated on this theme and created a dynamic theoretical model that helps to understand how this two spheres influence each other (see graph 1) ${ }^{10}$. Political power can be divided into two parts that not always go together. There are actors that wield de iure political power, i.e. that are responsible for legislation and execution of laws, and there are actors that hold de facto power, i.e. those that have enough resources to influence the shape of formal institutions by means of power and violence (like army or mob) or exerting pressure on actors wielding de iure power (like corruption or threats). It is thus political power, either de iure or de facto, that essentially determines economic and political institutions in society. Economic institutions influence both performance of the economy and subsequent distribution of resources, which determine de facto power. And last but not least, political institutions created by the interaction between de iure and de facto political power define future de iure power.

Graph 1. Relationship between economic and political institutions

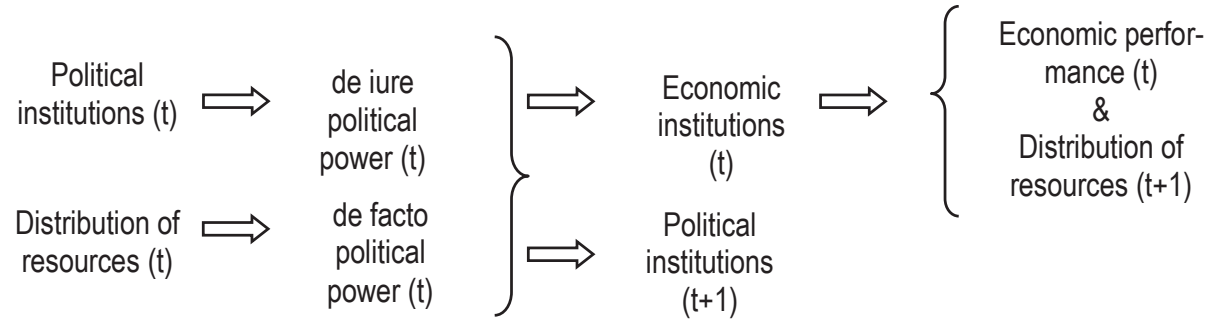

Source: D. Acemoglu, J.A. Robinson, Paths of Economic and Political Development, [in:] B.R. Weingast, D.A. Wittman (eds.), The Oxford Handbook of Political Economy, Oxford University Press, Oxford 2006, p. 677.

Distribution of power and consequently distribution of economic resources is a matter that is subject to constant change. In a society there will always be interest groups that are unsatisfied with the result of distribution. The question is, however, if they shall have enough power to change the institutional arrangements and what way they will choose to influence or change the distribution results. Therefore the authorities always try to ensure that de

${ }^{10}$ See D. Acemoglu, J.A. Robinson, Paths of Economic and Political Development, [in:] B.R. Weingast, D.A. Wittman (eds.), The Oxford Handbook of Political Economy, Oxford University Press, Oxford 2006. 
iure and de facto power is wielded in their hands so that the opposition to government is weak and limited. In a non-democratic society a change of institutions can occur only when actors of de facto power would have different preferences than actors of de iure power and would be willing to take the risk of change. This largely explains why dictatorships often fail to develop in economic terms preferring to crush or impoverish political opposition and oppose creation of free and prosperous society ${ }^{11}$. On the other hand, in a democratic society in which the government wields both de facto and de iure power parties unsatisfied with distribution results must either perform better economically or seek to influence the government to change the rules in their favor. This in turn causes other interest groups to find similar rent-seeking solutions which would make them better-off. It should be noted therefore that this process will most probably be infinite and will last as long as societies exist. The pure essence of the interaction between economic and political players is not a pursue of stable, long-lasting rules of the game, but their continuous adaptation to changing preferences and distribution of power. The process of institutional arrangements boils down to pushing the system out of equilibrium in order to find a new, temporary balance point. This clearly implies that institutional evolution does not seek any social or economic arrangements that would work best for economic growth or general welfare of society simply because such an optimal point does not exists due to conflicting preferences of actors and change of preferences over time. It is verve and unpredictability of human behavior that makes us suspicious of the notion of any permanent social or economic equilibrium. The world outside is dynamic, not static. After leaving his post at the World Bank Joseph Stiglitz stated that there are three things that determine economic reforms: ideas, interests, and coalitions ${ }^{12}$. So even if we exclude ideas for their metaphysical character, we can easily see that interests and coalitions noticeably fit to the above scheme of dialectical development. Any institutional arrangement is just a starting point for a next shift or, in other words, is a new set cards in hand that governs our benefits, possibilities of change, and risks linked to it. Institutions are one of the reasons that the world constantly changes and at the same time institutions like social norms or ways of behavior influence the path of its evolution.

${ }^{11}$ See S. Czech, System sprawowania wtadzy a wzrost i rozwój gospodarczy, [in:] S. Swadźba (ed.), Systemowe uwarunkowania wzrostu i rozwoju gospodarczego. Zagadnienia teoretyczne, Uniwersytet Ekonomiczny w Katowicach, Katowice 2013.

12 J.E. Stiglitz, Development Thinking at the Millennium, [in:] Proceedings from the Annual Bank Conference on Development Economics 2000, World Bank, Washington 2001, p. 30. 
Second thing is that it is up to the existing institutional matrix (and technology level) what kind of actions are possible and acceptable to perform within given societies. On the one hand there are social norms that require internalization and often voluntary compliance and on the other there is the law with given level of enforceability and reliability. This means, however, that not all human activities will be within the range of formal institutions. First, the law cannot regulate everything. It would be both impossible and undesirable due to waste of resources and strangling of social system dynamics. And second, formal institutions are not able to keep up with the pace of evolution and change in the modern world. Revolutionary change in the field of communication and information technologies in combination with the liberalization of lifestyle and economic regulations cause both lag and gap between reality and legislative process. The existing formal institutions seem to last as responses to the problems of the past in the path-dependent manner or are a result of interest groups' attempts to change the law in their favor. Of course it would be too simplistic to claim that the modern legislature does not respond to current issues. The changes in the law are introduced on regular basis, but the point is that this process is rather slow and selective and is not able to cover all the problems. It becomes thus increasingly evident that it is informal institutions that slowly take over the responsibility for the social order when the state is not any more capable of or does not wish to have the change under control. Social norms and shared patterns of behavior have an effect on modes of competition between economic actors, law obedience or tolerance for rent-seeking. They determine the customary framework of action (for example when it comes to marketing pushiness, respect for customer or for public sphere) and are responsible for the pressure for the change of formal institutions. Thus the state is nowadays not a classic-liberal night watchman and not even an impartial moderator of economic rules of the game as ordoliberals would like it to be. The state sanctions certain behaviors (like lobbying or monopoly power) and takes part in the distribution of economic resources in the politics and on the market. A weak state, that yields to certain interest groups, is no longer a keeper of public interest, but rather gradually becomes a legislator device of secondary meaning, which may eventually find itself distrusted or rejected by the society. Understanding the change of modern societies requires nowadays a much closer look at the social and informal rules of the game as these seem to slowly take over many aspects of socioeconomic reality. 


\section{CONCLUSION}

We see now that all institutional arrangements cause specific distribution effects that provoke a drive to change of the very same institutions and that informal norms and modes of behavior seem to have the greatest power to shape social order when the state withdraws from the control over it for a variety of reasons. A deeper understanding of a huge share of societies' evolution depends thus increasingly on the study of informal institutions. Social norms and patterns of behavior are part of every social system and as such are also an integral part of economic domain. They will sooner or later broaden the field of economic research, possibly in the manner of welcoming the post-veblenian tradition into the group of more popular currents of study. The reason for this is, as we believe, that at a certain stage of development social norms become either a barrier or a catalyst of economic growth and development. Together with formal institutions they influence the level of transaction costs, create various incentives for human actions, and determine the possible range of these actions. For example, a factor of trust in the study of economic development may lead to different conclusions depending on the way we consider it: either through the prism of rational utility maximizing behavior or from the perspective of socio-cultural norms obeyed by individuals. Regrettably values which are desirable from the economic point of view will not always go in hand with rational self-interested behavior. As has been recently demonstrated by David C. Rose, it is extremely important because trust treated as an exercise in rationality will generate higher transaction costs than trust employed as an unconditional norm of acting ${ }^{13}$. On the one hand, specialization is a key to prosperity, yet on the other, with specialization comes the risk of falling victim of opportunistic behavior. In situation when an employee is granted a great deal of freedom, flexibility, and initiative or only an employee has access to company's localized knowledge, there exists a strong incentive for fraudulent behavior which may be rational when it comes to maximizing his or her welfare. This is amplified when the risk of detection is minimal, nobody would ever find out or the harm done is hardly visible to a supervisor. However, inclusion of control mechanisms in employment contract would kill the initiative and creativity of the employee and may also prove too costly. Thus the self-enforcement or monitoring of rules do not work in this situation. Integrity of employees is not a thing a company can buy on the labor market. Rational behavior does not resolve satisfactorily the issue of trust and

${ }_{13}$ D.C. Rose, The Moral Foundation of Economic Behavior, Oxford University Press, Oxford 2011. 
honesty - it is a matter of cultural norms and social values. And in today's increasing complexity of economic processes, contracts, advanced research, innovation and international fierce competition this intangible factors are of utmost importance. Norms and values are thus a factor of growth that require much better recognition. Also the market mechanism is far from being neutral towards these values and the character of transaction items ${ }^{14}$. This is a kind of paradox that ruthless competition that was supposed to bring welfare to society has become a destructive force precisely because of damaging social norms and values which are not easily renewable and at some point become an important element of human capital and a factor of growth. This situation also affects possibilities of coordination of interests and goals of economic actors as well as the steering ability of the whole social system.

So is there a possibility to conduct research on what institutions enable in a specific social and historical context? For this to happen economics would need to become more open to other social sciences with special focus put on sociology or political philosophy. Pierre Bourdieu's concept of habitus seems promising when it comes to recognizing that human incentives, expectations, ambitions, patterns of thought and action, norms and values are created in a specific environment ${ }^{15}$. Precisely due to habitus there are given possibilities of action that an actor would take up and other options that he or she would not even think of. It thus determines the scope of action for each and every individual claiming that human cognitive abilities are very limited and rational behavior is bounded by mental condition and predispositions. The concept of institutional change, very well identified in modern economics, can profit from the extension to similar concepts of change in sociologi$\mathrm{cal}$, historical and political perspective ${ }^{16}$. The dialectical process of change that we have mentioned above stemming from distributional reasons and causing an infinite pursue of changing the rules of the game has lately been recognized by Vivien A. Schmidt ${ }^{17}$ who claims that studying a discursive side of the change (like construction of meanings and signs, ways of communication, usage of symbolic violence etc.) will give us much better view of social

${ }^{14}$ More on this issue see M.J. Sandel, What Money Can't Buy: The Moral Limits of Markets, FSG, New York 2012.

${ }_{15}$ For introductory texts see Grenfell M. (ed.), Pierre Bourdieu. Key Concepts, Acumen, Durham 2008.

${ }^{16}$ See for example J. Mahoney, K. Thelen, A Theory of Gradual Institutional Change, [in:] J. Mahoney, K. Thelen (eds.), Explaining Institutional Change. Ambiguity, Agency and Power, Cambridge University Press, Cambridge 2010.

17 See for example V.A. Schmidt, Speaking of Change: Why Discourse Is Key to the Dynamics of Policy Transformation, „Critical Policy Studies”, Vol. 5, No. 2/2011. 
transformations and social order. There are also many other paths that economics can follow in order to become better empirical and social science. Institutions may prove to be a good starting point.

\section{BIBLIOGRAPHY}

Acemoglu D., Robinson J.A., Paths of Economic and Political Development, [in:]

B.R. Weingast, D.A. Wittman (eds.), The Oxford Handbook of Political Economy, Oxford University Press, Oxford 2006.

Aoki M., Toward a Comparative Institutional Analysis, MIT Press, Cambridge 2001.

Czech S., System sprawowania władzy a wzrost i rozwój gospodarczy, [in:] S. Swadźba (ed.), Systemowe uwarunkowania wzrostu i rozwoju gospodarczego. Zagadnienia teoretyczne, Uniwersytet Ekonomiczny w Katowicach, Katowice 2013.

Greif A., Institutions and the Path to the Modern Economy, Cambridge University Press, Cambridge 2006.

Grenfell M. (ed.), Pierre Bourdieu. Key Concepts, Acumen, Durham 2008.

Groenewegen J., Spithoven A., van den Berg A., Institutional Economics, Palgrave Macmillan, Basingstoke 2010.

Hodgson G.M., What Are Institutions?, „Journal of Economic Issues”, Vol. 40, No. $1 / 2006$.

Kasper W., Streit M.E., Boettke P.J., Institutional Economics. Property, Competition, Policies, Edward Elgar, Cheltenham 2012.

Mahoney J., Thelen K., A Theory of Gradual Institutional Change, [in:] J. Mahoney, K. Thelen (eds.), Explaining Institutional Change. Ambiguity, Agency and Power, Cambridge University Press, Cambridge 2010.

North D.C., Institutions, „Journal of Economic Perspectives”, Vol. 5, No. 1/1991.

North, D.C., Institutional Change: A Framework of Analysis, „Economic History”, 1994, http://128.118.178.162/eps/eh/papers/9412/9412001.pdf (02.10.2013).

Rose D.C., The Moral Foundation of Economic Behavior, Oxford University Press, Oxford 2011.

Sandel M.J., What Money Can't Buy: The Moral Limits of Markets, FSG, New York 2012.

Schmidt V.A., Speaking of Change: Why Discourse Is Key to the Dynamics of Policy Transformation, „Critical Policy Studies”, Vol. 5, No. 2/2011.

Stiglitz J.E., Development Thinking at the Millennium, [in:] Proceedings from the Annual Bank Conference on Development Economics 2000, World Bank, Washington 2001. Voigt S., How (Not) to Measure Institutions, "Journal of Institutional Economics”, Vol. 9, No. 1/2013, http://dx.doi.org/10.1017/s1744137412000148.

Ząbkowicz A., Wspótczesna ekonomia instytucjonalna wobec gtównego nurtu ekonomii, „Ekonomista”, No. 6/2003. 
